\title{
Farmers' perception of the epidemic of African Swine Fever in Nigeria
}

\author{
K. Adebayo and O.S. Sorungbe
}

Department of Agricultural Extension and Rural Development, University of Agriculture, P. M. B. 2240, Abeokuta, Nigeria. E. mail: kadebayo@unaab.edu.ng

\begin{abstract}
Livestock diseases constitute a great threat to protein availability in Nigeria. It is thus necessary to examine how much farmers know about some deadly diseases prevalent in their stock as it would afford the farmer a timely re-adjustment to prevent foreseeable losses. The focus of this study was to deternine farmers' level of awareness of African Swine Fever (ASF) in Agege Area of Lagos State, Nigeria. Primary data were collected with the use of a questionnaire administered to one hundred and twenty (120) respondents selected using the purposive sampling technique. Twentyseven (27) pig farms were also visited to obtain on-farm data on pig mortality during the ASF epidemic. It was revealed that there was inadequate awareness of the early symptoms and characteristic signs of ASF among the respondents. As such mortality of about 95 percent was recorded. The Chi square analysis showed no significant relationship between farmers' level of awareness of ASF and the location of their pig farms. There was also no significant relationship between pig stock population and farmers' contact with Extension agents. The study then concluded that extension services to pig farmers are currently inadequate. It therefore recommends that it be developed to ensure institutional support in cases of epidemic disease outbreaks. More so, possible ways should be sought to ensure a steady flow of agricultural information from the research institutes and universities to the ultimate users. Preventive measures should however be tanght to farmers to avoid the incidence of future disease outbreaks. Lastly, pig farmers are also advised to form associations that could serve as a pressure group in such cases of sector specific emergencies.
\end{abstract}

Keywords: Perception, epidemic disease, African swine fever

\section{Introduction}

Pigs are found in all climatic regions in the tropics. It has been shown that Nigeria has the second largest pig population in Africa with a herd population of 4.41 million (Bukar, et al., 1997). Pigs are produced in all parts of the Country except in the core North which is predominantly Muslim. Over the years, much emphasis have been placed on increasing beef supplies particularly in the urban markets. However, because of some economic problems and the long gestation period of cattle, an increase in the national herd and the rate of take off is invariably a slow process. For any 


\section{Adebayo and Sorunghe}

meaningful and rapid increase in meat supply within the short-run, it is necessary to consider animals with shorter gestation periods such as pigs. Pigs stand out and have. the greatest potential as contributor to increasing livestock output (FAO, 1968). Several factors influence the success of a pig farm. Pigiet losses at and about farrowing (Derek, 1973; Gadd, 1990a), pests and diseases management, the farmers' knowledge and use of improved production practices are important (Gadd, 1990b).

The central issue in the successful management of a pig farm however is for the farmer to know what to do, at the right moment. The failure or hesitation to do this may cost him a stock. To enhance the effective production of pigs and pig products, it would be necessary for pig farmers to be aware of the diseases plaguing the industry with a view to providing a reasonable entry point for agricultural extension work and services. This is more so, in the case of diseases which spreads easily, become fatal fast and with no known cure. One of such diseases is the African Swine fever (ASF). This viral disease can wipe out a pig stock within 72 hours of showing clinical sighs (Euysebio, 1980; Bushby, 1986). The disease is characterized by coughing, respiratory disorders and diarthorea. Bleeding is sometimes observed in the edges of the ears, snout, legs and belly. There is a bloody discharge from the nose and throat and a marked drop in white blood cell count (Bakshi, 1988; Eusebio, 1980). No effective serum or vaccine has yet been found for the disease. It can be transmitted by contact between healthy and infested animals, as well as by humans who traverse both infested and clean farms. The resistant virus can withstand high ambient temperatures and can thrive even in dried or decayed meat. It can therefore spread easily over a wide geographical area. Cases of ASF were reported early in 1998 in the Republic of Benin on the western boundary of Nigeria. In less than 6 months, pig stocks in
Lagos. Enugu and Kaduna in Nigeria were reportedly infected and wiped out by the disease.

Arising from the foregoing, this study determined farmers' level of awareness of ASF in Agege Area of Lagos, Nigeria. Specifically, the study: determined the level of knowledge of farmers about the disease; identified the extent and significance of the disease; evaluated extension message outreach to pig farmers in the study area and suggested possible ways of improving farmers' level of awareness of ASF in order to boost pig production in Nigeria.

\section{Methodology}

The study area for this research work is Agege Area of Lagos State Nigeria which was one of the entry points of the African Swine Fever (ASF) into the Country in 1998. Pig farmers were selected purposively selected from the different zones in the area. Structured question were administered to one hundred and twenty (120) respondents to elicit data on their knowledge of the disease and way of increasing such. Only one hundred (100) questionnaires could however be used for further analysis. Actual data on mortality during the ASF epidemic was also obtained from twenty-seven (27) farms personally visited by the researcher. Data analysis involved the use of descriptive statistical tools including percentages and frequency tables. The Chi square test at 5 percent level of significance was used to test two (2) null hypotheses. These are:

$\mathrm{Ho}_{4}$ There is no significant relationship between farmers' level of awareness of ASF and the location of their farms.

$\mathrm{Ho}_{2}$ There are no significant relationships between farmers' level of awareness of ASF and selected socio-economic characteristics (level of education, total access to credit income and membership of farmers' group). 


\section{Farmers' perception of African Swine-Fever}

$\mathrm{Ho}_{3}$ There is no significant relationship between the stock population of pig farms and their regularity of contact with Extension Agents.

\section{Results and discussion}

Description of respondents

The respondents interviewed in this study are mainly pig farmers in Agege Local Government area of Lagos State. The majority of these farmers ( 85 percent) are (Table 1) males between the ages of 21 and 60 years (Table 1). Similar distribution of pig farmers were described by Ekundayo (1999) and Sorungbe (2000). About half of the respondents had no formal education, but 6 percent had various forms of post-secondary education ranging from Ordinary Diploma to Master of Science degree. Previous studies have shown that education is a key factor in shaping the perception of farmers (Adebayo, in press; Adebayo and Adeyemi, 2000).

The respondents were asked to indicate their farm and non-farm incomes over a period of one month. The responses were grouped at intervals of $\$ 10,000.00$. The result shown in table 1 depicts that 68 percent of the respondents have total monthly income of less than $\$ 20,000.00$ twenty (20) percent of the respondents however earn incomes over N30,000.00 monthly.

Furthermore, the respondents indicated the number of farmers' groups to which they belong. Table 1 shows that most of the pig farmers (86 percent) belong to various farmers' groups ranging from one to three. Adebayo and Adeyemi (2000) however shows that most of such groups have been less than effective in meeting their members aspirations.

Lastly, 90 percent of the respondents have no access to credit. Even though this may be so, field experiences have shown that most farmers do not often disclose their access to credit (Wesby et al. in press).

Farmer's knowledge of African Swine Fever For this analysis, the criteria used to determine farmer's knowledge of African Swine Fever were: their knowledge of the rate of spread of the disease, its mortality rate, incubation period, symptoms and treatment of the disease. A farmers' ability to describe any of these criteria gives him a score of one(1) mark. So, a farmer who can explain all five(5) criteria has a score of five (5) while one who cannot explain any of the criteria has a score of zero (0).

Table1 Distribution of respondents based on some socio-economic characteristics

\begin{tabular}{ll} 
Characteristics & $\mathrm{n}=100$ \\
\hline Sex & \\
Male & 85.0 \\
Female & 15.0 \\
Age & \\
Less than 21 years & 2.0 \\
21-40 years & 43.0 \\
$41-60$ years & 42.0 \\
Above 60 years & 13.0 \\
Level of education & \\
No formal education & 52.0 \\
Primary education & 25.0 \\
Secondary education & 17.0 \\
Post secondary education & 6.0 \\
Total income & \\
Less than N10,000/monthly & 36.0 \\
10,001-20,000 & 32.0 \\
20,001-30,000 & 12.0 \\
30,001-40,000 & 17.0 \\
Above N 40,000 & 3.0 \\
Membership of firmers' group & \\
None & 8.0 \\
1 groups & 28.0 \\
3 groups & 36.0 \\
3 groups & 22.0 \\
Above 3 groups & 6.0 \\
Access to credit & \\
Yes & 8.0 \\
No & 92.0 \\
\hline \hline
\end{tabular}




\section{Adebayo and Sorungbe}

On the aggregate, respondents who scored between 0-2 marks had little or no knowledge of African Swine Fever while those that scored between 3-5 marks had good knowledge of African Swine Fever.

As shown in Table 2, 13 percent of the respondents had very poor knowledge of African Swine Fever and thus scored zero. The majority of the respondents ( 30 percent) scored two, while over 40 percent had above average knowledge of ASF. This implies that majority (50 percent) of respondents have a below average knowledge of the disease. This is unfortunate given that the disease is vital and as such cannot be treated after infection. Moreso, when it can wipe out stock of pig in about 72 hours after introduction.

Relationship between farmers' level of awareness of ASF and selected socio-economic characteristics

The chi-square analysis was used to establish the relationship between the level of awareness of ASF and four socio-economic characteristics of the farmers. The results shown in Tables 3 , 4,5 and 6 indicate that there are no significant relationship between farmers' level of awareness and their total access to credit. A significant relationship $(\mathrm{P}<0.05)$ was however established between farmers' level of awareness of ASF and their level of education. The results corroborate the finding of Sobowale (1999) that education is a key factor affecting pig production. This is moreso; as disease prevention and management demand some level of literacy to diagnose the symptoms, understand the treatments required and administer the medicaments.

Extent and Significance of African swine fever in Agege area of Lagos State

The kind of pigs available on the twenty-seven (27) farms visited are boars, fatteners, sow, weaners, piglets, finishers and gilts. The extents of mortality due to the scorage of African Swine Fever on the farms is shown in Table 7.

Table 2 Percentage distribution of pig farmers on their knowledge of African Swine Fever

\begin{tabular}{lll}
\hline Knowledge Score & Percent $n=100$ & Interpretation \\
\hline 0 & 13.0 & Very poor \\
1 & 15.0 & Poor \\
2 & 30.0 & Fair \\
3 & 28.0 & Average \\
4 & 12.0 & Good \\
5 & 2.0 & Very Good \\
Total & 100 & \\
\hline
\end{tabular}

Source: Sorungbe (2000)

Table3 Contingency table showing farmers' level of awareness of ASF and level of education.

\begin{tabular}{|c|c|c|c|c|c|}
\hline Measurement & $\begin{array}{l}\text { No formal } \\
\text { education }\end{array}$ & $\begin{array}{l}\text { Primary } \\
\text { education }\end{array}$ & $\begin{array}{l}\text { Secondary } \\
\text { education }\end{array}$ & $\begin{array}{l}\text { Post secondary } \\
\text { education }\end{array}$ & Total \\
\hline Knowledge of ASF & $4(21.84)$ & $\overline{17(10.5)}$ & $15(7.14)$ & $6(2.52)$ & 42 \\
\hline $\begin{array}{l}\text { No good knowledge } \\
\text { of ASF }\end{array}$ & $48(30.16)$ & $8(14.5)$ & $92(9.84)$ & $0(3.48)$ & 58 \\
\hline Total & 52 & 25 & 17 & 6 & 100 \\
\hline
\end{tabular}




\section{Adebayo and Sorungbe}

Tabie 4 Contingency Table Showing Farmers' Level of awareness of ASF and their Total income

\begin{tabular}{|c|c|c|c|c|c|c|c|c|}
\hline Measurement & \multicolumn{2}{|c|}{$\begin{array}{l}\text { Less than } \\
\text { N10,000 }\end{array}$} & \multicolumn{2}{|c|}{$10,00120,000$} & $\begin{array}{l}20,001 \\
30,000\end{array}$ & $30,00140,000$ & $\begin{array}{l}\text { Above } \\
40,000\end{array}$ & Total \\
\hline \multirow{3}{*}{$\begin{array}{l}\text { Knowledge } \\
\text { of ASF } \\
\text { No of good } \\
\text { knowledge } \\
\text { of ASF }\end{array}$} & $\begin{array}{l}12 \\
(15.12\end{array}$ & & \multicolumn{2}{|c|}{$14913.44)$} & $6(5.04)$ & $8(7.14)$ & $2(1.26)$ & 42 \\
\hline & $\begin{array}{l}24 \\
(20.88\end{array}$ & & \multicolumn{2}{|c|}{$18(18.56)$} & $6(6.96)$ & $9(9.86)$ & $1(1.74)$ & 58 \\
\hline & 36 & & \multicolumn{2}{|c|}{32} & 12 & 17 & 3 & 100 \\
\hline \multicolumn{9}{|c|}{$\begin{array}{l}\mathrm{df}=4 \quad{ }^{2} \text { o. }=9.49 \quad 7^{2} \text { cal }=2.38 \\
\text { Decision: Since }{ }^{2} \text { cal }<7_{0.05}^{2} \text { do not reject Ho }\end{array}$} \\
\hline Measurement & & No & & 1 group & 2 groups & 3 groups & $\begin{array}{l}\text { Above } \\
\text { groups }\end{array}$ & Total \\
\hline \multicolumn{2}{|c|}{ Knowledge of ASF } & $2(3$ & 36) & $11(11.76)$ & $1717(15.12$ & $8(9.24)$ & $4(2.52)$ & 42 \\
\hline \multicolumn{2}{|c|}{$\begin{array}{l}\text { No good knowledge } \\
\text { of ASF }\end{array}$} & $6(4$ & 64) & $17(16.24)$ & $19(20.88)$ & $14(12.7)$ & $2(3.48)$ & 58 \\
\hline Total & & 8 & & 28 & 36 & 22 & 6 & 100 \\
\hline
\end{tabular}

df $=4{ }^{2}{ }_{0.05}=9.49 \quad{ }^{2}$ cal $=3.22$

Decision: Since ${ }^{2}{ }_{\text {cal }}<{ }_{0.05}$ do not reject Ho

Table 6 Contingency table showing farmers 'level of awareness of ASF and their access to credit

\begin{tabular}{llll}
\hline Measurement & Access to credit & No Access to credit & Total \\
\hline Knowledge of ASF & $5(3.36)$ & $37(38.64)$ & 42 \\
No good knowledge of ASF & $3(4.64)$ & $55(53.36)$ & 58 \\
Total & $\mathbf{8}$ & 92 & 100 \\
\hline
\end{tabular}

$\mathrm{df}=4 \quad{ }^{2}{ }_{0.05}=5.99 \quad !^{2}$ cal $=1.5$

Decision: Since : ${ }^{2}$ cal $<{ }^{2}$ o.0s do not reject Ho

Table 7 Percentage mortality of pigs during the ASF epidemic on the farms visited

\begin{tabular}{llll}
\hline Kind of Pig & No in stock & Mortality & Percentage mortality \\
\hline Boars & 230 & 228 & 99.13 \\
Fatteners & 270 & 206 & 76.30 \\
Sow & 160 & 159 & 99.38 \\
Weaners & 825 & 823 & 99.76 \\
Piglets & 850 & 802 & 94.35 \\
Finisher & 225 & 200 & 88.89 \\
Gilt & 150 & 149 & 99.33 \\
Total & 2710 & 2567 & 94.72 \\
\hline
\end{tabular}

221

Sorungbe (2000) 
The Table 7 shows that mortality due to ASF was $\mathbf{9 4 . 7 2}$ percent. In fact among boars, sows, weaners and gilts, this value is as.high in 99 percent. Mortality is however lowest among fattners. It is possible however that the fattners were slaughtered and dressed as soon as the pigs began to die. Since ASF is not known to be zoonotic. It was reported however that most of the pigs died a few hours after the onset of clinical signs of mental depression, vomiting and respiratory distress. Majority (63 percent) of the respondents claimed that mortality due to African Swine fever resulted in economic ruin of their savings. Many pig farmers and their pen hands have also being thrown into the employment market, as many farmers are wary of continuing the business of rearing pigs. The Chi-square analysis at $5 \%$ significance level shows no significant relationship between farmers level of awareness of African Swine Fever and the location of pig farmers in the study area (Table 8). This may be due to the relative ease with which the disease can be transmitted from farm to farm. It is also suspected that the slaughtering of fatteners infected by the disease may have aided its spread throughout the study area, since meat from such infected animals carry potential inoculum for the disease which could be spread to healthy animals.

The access of pig farmers to extension services For the purpose of this study, the respondents were divided into groups according to the stock population. Group 1 refers to those with stock population of less than 20 pigs while group 2 refers to those with stock population of above 20 pigs. Thus, representing backyard, and medium sized pig production respectively (Eusebio 1980).

The Table 9 shows that most pig farmers (59 percent) never had these contact with extension agents. This means that production recommendations from the research institutes and universities does not get to a greater proportion of farmers. The result of the Chisquare analysis (Table 9) shows no significant relationship between stock population and regularity of contact with extension agents. This seems to indicate that farmers' contact with extension services had no relationship with stock population. Extension services should bear some positive impact on improving production practices.

Table 8 Contingency table showing Farmers' level of awareness of African Swine Fever and the location of pig farm in Agege area

\begin{tabular}{lllllll}
\hline Measurement & Location of pig farmers & & & & \\
\hline & Agege township & $\begin{array}{l}\text { Oko- } \\
\text { Oba }\end{array}$ & Orile & Ogba & $\begin{array}{l}\text { Oke- } \\
\text { Koto }\end{array}$ & Total \\
Knowledge of African & $9(8)$ & $12(8)$ & $7(8)$ & $6(8)$ & $8(8)$ & 42 \\
$\begin{array}{l}\text { Swine fever } \\
\text { No good knowledge of }\end{array}$ & $11(12)$ & $8(12)$ & $13(12)$ & $14(12$ & $12(12$ & 58 \\
$\begin{array}{l}\text { African Swine fever } \\
\text { Total }\end{array}$ & 20 & 20 & 20 & 20 & 20 & 100 \\
\hline
\end{tabular}

Sorungbe (2000)

$\mathrm{df}=4 ; \quad{ }_{0.05}^{2}=9.49 \quad{ }^{2} \mathrm{cal}=2.58$

Decision: Since $\therefore{ }^{2}$ cal $<{ }_{0.05}^{2}$ do not rejected null hypothesis 


\section{Adebayo and Sorungbe}

Table 9 Contigencu table of the relationship between stock population and pig farmers regularity of contact with extension agents

\begin{tabular}{llllllll}
\hline Output & $\begin{array}{l}\text { Never had } \\
\text { contact }\end{array}$ & $\begin{array}{l}\text { Once in a } \\
\text { weeks }\end{array}$ & $\begin{array}{l}\text { Once in two } \\
\text { weeks }\end{array}$ & $\begin{array}{l}\text { Once in three } \\
\text { weeks }\end{array}$ & $\begin{array}{l}\text { Once in a } \\
\text { month }\end{array}$ & Total \\
\hline 1 & $(33.63)$ & $95.7)$ & $(11.4)$ & $(2.28)$ & $(3.99)$ & 57 \\
2 & $(25.37)$ & $(4.3)$ & $(8.6)$ & $(1.72)$ & $(3.01)$ & 43 \\
Total & 59 & 10 & 20 & 4 & 7 & 100 \\
\hline
\end{tabular}

Source Sorungbe (2000)

df $=4 ; \quad 1 \hbar^{2}{ }_{0.05}=9.49 \square^{2}$ cal $=5.62$

Decision: Since $\Gamma !^{2}$ cal $<\Pi^{2}{ }_{0.05}$ do not reject null hypothesis

Table 10 Farmers' Suggestions for improving awareness on ASF

\begin{tabular}{lll}
\hline Suggestion & $\mathrm{N}-100$ & Rank \\
\hline Use of radio programmes & 42.0 & 1 \\
Use of symposium & 28.0 & 2 \\
Use of bulletins and poster & 20.0 & 3 \\
Use of film shows & 10.0 & 4 \\
Total & 100 & \\
\hline
\end{tabular}

Source: Sorungbe $(2000)$

Possible ways of improving awareness of African Swine Fever among farmers

The respondents in this study were asked to suggest ways by which their awareness of ASF could be improved. Some of the suggestions include the use of radio programmes, symposium (talk), film shows and the use of bulletins and posters to stimulate audience interest to search for more information from relevant agencies.

As shown in Table 10,42 percent of the respondents agreed on the use of radio programmes, 28 percent prefer the use of symposium, 20 percent prefer the use of bulletins and poster while 10 percent of the respondents favoured the use of film shows. The overall preference for the radio as a means of generating awareness may be attributed to the widespread ownership of radio sets among farmers and the easy access of the audience to messages aired on radio (Adebayo, 1997). Furthermore, these communication aids could be complemented with visit to ideally managed farms and training workshop on disease prevention and management. This will serve to improve farmers' knowledge and further help tackle the menace of any potential future epidemy.

\section{Conclusion and recommendations}

The outbreak and spread of African Swine Fever in Nigeria could have been averted if farmers have adequate knowledge of its early symptoms and characteristic signs. In most cases visited during this study, preventive measures were not observed to avoid or reduce incidence and spread of the disease. Furthermore, there is inadectuate knowledge of the existence of veterinary or extension which could have helped when the earliest cases of the disease were observed. This is a serious indictment of the Disease Monitoring and Quarantine Departments of the Ministry of Agriculture. Therefore, it is expedient that way's should be sought to ensure easy flow of 


\section{Farmers' perception of African Swine Fever}

agriculture information from the research institutes, universities and knowledgeable farmers to the pig farmers.

Furthermore, it is necessary that relevant government agencies should be sensitive to national disasters as was done in rinder-pest epidemic that ravaged cattle herds in the mid1990s. Moreover, the institutional framework provided by the Agricultural Development programme (ADP) in the country could be used to monitor and inform farmers about relevant production recommendations as preventive and ready-for-use extension messages. In fact, the veterinary office could form part of the trainers at the monthly technology Review Meetings (MTRM) of the ADPs to provide the information that could be readily useful to pig farmers.

Similarly, the Environmental Waste Management board should ensure that garbage at international airports and sea ports as well as all food left-overs from planes and ship should be incinerated, rather than the careless open disposal methods currently in use where roaming pigs have direct access to such refuse heaps.

Lastly, pig farmers can also form cooperatives or associations to obtain relevant assistance from governmental and non-governmental agencies. Such associations could serve as pressure groups in meeting the needs of their members in cases of emergencies such as the ASF:

\section{References}

Adebayo, K. 1997. Communication in Agriculture Green links International. Abeokuta, Nigeria 102pp.

Adebayo, K. "Gender and Cosmopolitanism as factors influencing maize technology adoption". The Nigerian rural Sazinas. (Jn Press).

Adebayo, K. and Adeyemi, E. T. 2000. Ke issues in the sustainability of farmers groups in Ogun State". Paper presented $x$ the $6^{\text {th }}$ Annual conference of the Agricultural Extension society of Nigeria held at the University of Ibadan, Ibadan. 2001 .

Bakshi, J. S. 1988. Swine Production Mc Graw-Hill Publications, London, U. K. 328pp.

Bukar, S.; Adamu, A. and Bakshi, J. S. 1997. Nigeria 1997 National agricultural Strategy Plan 1996-2001 EMA, Abuja, Nigeria. 280pp.

Bushby, R. 1986. "Pigs" In: Thear, K. and Fraser, A. 1986. The complete Book of Raising Livestock and Poultry. Nigeria Edition. University Services Ltd. Educational Publishers, Ibadan, Nigeria. Pp. 140-158.

Derek, H. G. 1973. "Pig Management and Production" Longman 216pp

Ekundayo, B. 1999. "African Swine Fever - A threat to Nigeria Pig industry" A paper presented at the inauguration of Pig Farmers Association of Lagos State. Unplished $14 \mathrm{pp}$.

Eusebio, J. A. 1980. Pig Production in the Tropics_Longman. $115 \mathrm{pp}$.

Fao 1968. Freedom from Hunger Report of Agricultural Statistics Task Force. Food and Agriculture Organisation of the United Nations 10pp.

Gadd, J. 1990a. "Increase profits, save newborn pigs" Agribusiness Worldwid:: Vol. 12, No.3, pp \3-16. 


\section{Adebayo and Sorungbe}

Gadd, J. 1990b. "Valued qualities of the good pig farm manager". Agribusiness Worldwide. Vol. 12, No. 1, pp 22-24.

Nuru, S. 1975. "The changing role of Veterinary Profession in National Development Programmes" ABU Public Lectures, February 1975.

Sobowale, A. 1999. "Factors affecting pig production in Ikorodu" B. Agric. Project. University of Agriculture, Abeokuta. Unplished 43pp.
Sorungbe, O. S. 2000. "Farmers" level of awareness of African Swine Fever (ASF) in Agege Local Government area of Lagos State. B. Agric Project. University of Agriculture, Abeokuta. Unplished. 52pp.

Westby, A., Dipeolu, A. O., Adebayo, K. White, J. L., Pearce, D. M., Oyewole, $O$. B. and Sanni, L. O. Current and potential future markets for fufu in southwest Nigeria. UNAAB/NRI-DFID sponsored study. 50pp. (in press)

(Received 30 May 2000; Accepted 13 June 2001) 